\title{
KERUSAKAN PASCAPANEN PADA UBI KAYU HASIL PEMULIAAN SELAMA PENYIMPANAN
}

\section{POSTHARVEST DETERIORATION OF BREEDING CASSAVA DURING THE STORAGE}

\author{
Rina Heldiyanti $^{1 *}$, Sutrisno ${ }^{1}$, Nurul Khumaida ${ }^{2}$ dan Emmy Darmawati ${ }^{1}$ \\ ${ }^{1}$ Teknologi Pascapanen, Departemen Teknik Mesin dan Biosistem, Institut Pertanian Bogor \\ Kampus Dramaga, Bogor, Indonesia \\ ${ }^{2}$ Bioteknologi Tanaman, Departemen Agronomi dan Hortikultura, Institut Pertanian Bogor \\ Kampus Dramaga, Bogor, Indonesia \\ *Email: rheldiyanti@gmail.com
}

\begin{abstract}
Postharvest deterioration is a major problem which is an obstacle for cassava handling both for conventional cassava variety and mutant variety. There are two types of postharvest deterioration on cassava, namely postharvest primary deterioration (PPD) or primer deterioration of physiological deterioration, and microbiological deterioration. Damage can be minimized by carrying out storage in optimal conditions. This study aimed to determine the level of postharvest deterioration on cassava variety $R$ and $U$ during 35 days of storage. The storage treatment was storage consist of 1) wooden boxes and moist sawdust storage (P1) and 2)control storage (P2). The results indicated that RP2 and UP2 produced physiological deterioration by $25 \%$ on the 7 th day of storage and reached $100 \%$ on the 35 th day of storage. Meanwhile, the percentage of microbiological deterioration reached more than $20 \%$ on the 14 th day of storage. On the other hand, RP1 and RP2 indicated good results. Both varieties experienced only less than 25\% physiological deterioration and did not experience microbiological deterioration during storage.
\end{abstract}

Keywords: Cassava, microbiological deterioration, physiological deterioration, storage conditions, sawdust

\begin{abstract}
ABSTRAK
Kerusakan pascapanen merupakan permasalahan utama yang menjadi hambatan dalam penanganan ubi kayu baik ubi kayu varietas lokal maupun ubi kayu hasil induksi mutasi. Terdapat dua kerusakan pascapanen pada ubi kayu yaitu postharvest primary deterioration (PPD) atau kerusakan primer atau disebut juga kerusakan fisiologis serta kerusakan mikrobiologis atau disebut kerusakan sekunder. Kerusakan dapat diminimalisir dengan melakukan penyimpanan dalam kondisi yang optimal. Penelitian ini bertujuan untuk mengetahui tingkat kerusakan pascapanen pada ubi kayu selama 35 hari penyimpanan pada varietas $\mathrm{R}$ dan U. Perlakuan penyimpanan yang digunakan yaitu: 1) penyimpanan dengan menggunakan kotak kayu dan serbuk kayu (P1) dan 2) penyimpanan kontrol (P2). Hasilnya menunjukkan bahwa pada perlakuan RP2 dan UP2 di hari ke-7 penyimpanan menghasilkan persentase kerusakan fisiologis $25 \%$ dan mencapai $100 \%$ pada hari ke 34 penyimpanan. Sementara itu persentase
\end{abstract}


kerusakan mikrobiologisnya mencapai lebih dari $20 \%$ pada hari ke-14 penyimpanan. Berbeda dengan perlakuan RP1 dan UP1 yang hanya mengalami kerusakan fisiologis sebesar 25\% dan tidak mengalami kerusakan mikrobiologis selama penyimpanan.

Kata Kunci : Kerusakan fisiologis, kerusakan mikrobiologis, kondisi penyimpanan, serbuk kayu, ubi kayu

\section{PENDAHULUAN}

Meningkatnya kebutuhan ubi kayu di masa mendatang mendorong pengembangan varietas ubi kayu baru yang unggul. Pengoptimalan produksi ubi kayu sebagai bahan pangan dapat dilakukan dengan mengembangkan karakter penting pada ubi kayu yaitu produktivitas tinggi dan kadar pati tinggi. Upaya untuk mendapatkan karakter yang diinginkan tersebut adalah dengan melakukan suatu program pemuliaan dengan syarat keragaman genetik tanaman yang tinggi (Khumaida et.al, 2015).

Salah satu cara peningkatan keragaman genetik adalah dengan induksi mutasi. Metode pemuliaan yang umum digunakan untuk meningkatkan variasi genetik pada tanaman vegetatif seperti ubi kayu adalah dengan induksimutasi menggunakaniradiasi sinar gamma. Metode ini dapat menghasilkan varietas ubi kayu baru yang unggul (Yani et.al, 2018).

Namun, permasalahan pascapanen pada ubi kayu baik varietas lokal maupun hasil pemuliaan menjadi salah satu hambatan dalam pengolahannya. Ubi kayu cepat mengalami kerusakan pascapanen. Kerusakan pada ubi kayu dibagi menjadi kerusakan fisiologis dan kerusakan mikrobiologis (Ginting, 2002). Kandungan air yang cukup tinggi yaitu sekitar $65 \%$ menyebabkan ubi kayu sangat mudah rusak (Haloho, 2014).
Ubi kayu hasil-hasil induksi mutasi yang selanjutnya disebut ubi kayu hasil pemuliaan. Ubi kayu hasil pemuliaan yang berasal dari varietas Gajah hanya dapat disimpan hingga 6 hari di dalam suhu ruang. Kerusakan dimulai dengan perubahan warna umbi dari putih menjadi kecoklatan atau kehitaman dan diakhiri dengan pembusukan umbi. Penurunan bobot umbi mengalami peningkatan, sedangkan kadar pati dan air mengalami penurunan seiring dengan lamanya penyimpanan. Sementara itu ubi kayu varietas lokal hanya dapat disimpan selama 48 jam (Noerliyanti, 2017).

Salah satu upaya yang dapat dilakukan untuk meminimalisir kerusakan pascapanen adalah melalui penyimpanan dengan modifikasi kondisi lingkungan dalam kondisi yang optimal. Kondisi optimal untuk penyimpanan ubi kayu adalah pada suhu $26.5-29.3^{\circ} \mathrm{C}$ $\left(80^{\circ}-85^{\circ} \mathrm{F}\right)$ dengan kelembaban relatif $(\mathrm{RH}) 90-95 \%$ (Osunde dan Fadeyibi, 2011).

Oleh karena itu penelitian ini bertujuan untuk mengetahui tingkat kerusakan pascapanen pada ubi kayu hasil pemuliaan yang berasal dari varietas Ratim dan dan varietas UJ-5 selama penyimpanan.

\section{BAHAN DAN METODE}

\section{Bahan dan alat}

Bahan utama yang digunakan dalam penelitian 
ini adalah ubi kayu hasil pemuliaan yang berasal dari varietas Ratim (R) dan varietas UJ-5 (U), masingmasing berumur 10 bulan dengan berat per umbi 400 gr dan panjang $20-27 \mathrm{~cm}$. Sementara itu alat yang digunakan adalah serbuk kayu, kotak kayu, wood moisture meter dan hygrometer.

\section{Penyimpanan}

Setelah dipanen, ubi kayu dipisahkan dari daun dan batangnya, kemudian dikumpulkan untuk disortasi. Tanah yang menempel pada ubi kayu tidak dibersihkan. Ubi kayu yang telah disortasi kemudian dikemas dalam karung plastik untuk kemudian diangkut menuju ruangan gudang penyimpanan. Terdapat dua kondisi penyimpanan untuk varietas $\mathrm{R}$ dan Varietas $\mathrm{U}$ yaitu:

1) Penyimpanan di dalam kotak kayu yang dilapisi serbuk kayu lembab (P1)

2) Penyimpanan kontrol (P2)

Dengan demikian terdapat 4 kombinasi perlakuan: RP1, RP2, UP1, dan UP2. Masing-masing kombinasi dulang sebanyak tiga kali ulangan, sehingga terdapat 12 unit perlakuan.

Jumlah umbi yang digunakan per ulangan adalah 10 buah. Jumlah kotak kayu yang digunakan adalah 6 kotak kayu $\left(\mathrm{RP} 1_{1}, \mathrm{RP} 1_{2}, \mathrm{RP} 1_{3}, \mathrm{UP} 1_{1}, \mathrm{UP} 1_{2}\right.$, dan UP $1_{3}$ ) dengan ukuran berukuran $50 \mathrm{~cm} \times 45 \mathrm{~cm} \times 25 \mathrm{~cm}$. Jumlah serbuk kayu yang digunakan adalah $2 \mathrm{~kg}$ per kotak.

Serbuk kayu dikondisikan dalam kondisi lembab agar memenuhi kondisi penyimpanan optimal untuk ubi kayu. Serbuk kayu lembab didapatkan dengan cara menambahkan air sedikit demi sedikit ke serbuk kayu hingga tercapai kadar air 14\% (Quevedo et.al, 2014). Kadar air ini dipertahankan dengan cara menambahkan air setiap hari ke serbuk kayu. Kadar air 14\% digunakan untuk menciptakan kondisi optimum (Suhu $26-28^{\circ} \mathrm{C}$ dan $\mathrm{RH} 70-90 \%$ ) untuk penyimpanan ubi kayu segar. Penyimpanan dilakukan selama 35 hari. Suhu dan RH baik di dalam kotak kayu maupun suhu dan RH lingkuangan diamati selama 35 hari penyimpanan.

Perlakuan kontrol dilakukan dengan menempatkan ubi kayu di atas lantai berbahan keramik. Penyimpanan di dalam kotak kayu dilakukan dengan melapisi bagian dasar kotak dengan serbuk gergaji lembab dengan ketebalan sekitar $1 \mathrm{~cm}$, kemudian ubi kayu disusun diatas lapisan tersebut dan ditutup kembali dengan serbuk gergaji lembab dengan ketebalan lapisan sekitar $5 \mathrm{~cm}$.

\section{Pengamatan}

Tingkat kerusakan yang diamati terdiri atas kerusakan fisiologis dan kerusakan mikrobiologis. Kerusakan fisiologis berupa goresan vaskular (vascular streaking) berwarna biru kehitaman atau kecoklatan yang searah jaringan pembuluh vaskular sementara itu kerusakan mikrobiologis berupa kebusukan umbi. Pengamatan dilakukan dengan langkah-langkah sebagai berikut:

1. Satu buah umbi untuk setiap ulangan dipotong melintang menjadi tiga bagian yaitu: pangkal, tengah dan ujung.

2. Tingkat kerusakan pada setiap bagian diamati secara visual berdasarkan skala ${ }^{7}$ pada Tabel 1 kemudian dirata-ratakan. 
Tabel 1. Skala tingkat kerusakan pada ubi kayu selama penyimpanan

\begin{tabular}{cc}
\hline Kerusakan fisiologis & Kerusakan mikrobiologis \\
\hline vaskular & $0=$ tidak busuk, \\
$2=25 \%$ goresan vaskular & $1=$ kebusukan $<20 \%$, \\
$3=26-50 \%$ goresan vaskular & $2=21-40 \%$ busuk \\
$4=50 \%$ goresan vaskular & $3=41-60 \%$ busuk \\
$5=76-100 \%$ goresan vaskular & $4=61-80 \%$ busuk \\
\end{tabular}

\section{Analisis Data}

Data hasil pengamatan diolah dengan statistika deskriptifmenggunakan software MS.Excel.

\section{HASIL DAN PEMBAHASAN}

\section{Suhu dan RH selama penyimpanan}

Tercatat bahwa suhu rata-rata selama 35 hari di dalam kotak kayu stabil pada nilai $27-28^{\circ} \mathrm{C}$ sedangkan RH stabil pada 80-90\%. Hal ini sesuai dengan kondisi optimum untuk penyimpanan ubi kayu segar yaitu $26.5-29.3^{\circ} \mathrm{C}$ dengan $\mathrm{RH}$ 90-95\%. Pada kondisi ini, aktivitas fisiologis yang menyebabkan kerusakan berjalan lebih lambat sehingga umur simpan ubi kayu dapat diperpanjang (Babarinsa dan Oluwalana, 2018). Serbuk kayu mempunyai kemampuan untuk mempertahankan jumlah air yang diserapnya, sehingga hal ini sangat membantu dalam menjaga mempertahankan kondisi penyimpanan yang optimal (Maharani et.al, 2010).

\section{Kerusakan Fisiologis}

Postharvest physiology deterioration (PPD) telah menjadi salah satu permasalahan dalam pemasaran ubi kayu. Hal ini dipicu oleh kerusakan fisik pada umbi saat proses panen (Saravanan et.al, 2015). PPD merupakan sebuah proses yang kompleks yang dihubungkan oleh gangguan yang terjadi pada enzim saat luka, melibatkan perubahan dalam ekspresi gen, sintesis protein, dan akumulasi metabolit sekunder. Kerusakan primer juga melibatkan perubahan dalam aktivitas enzim oksidatif yang menghasilkan senyawa fenol, termasuk katekin dan leukoantosianidin yang kemudian mengalami polimerisasi dalam tahap berikutnya untuk membentuk tannin (Sa'nchez et.al, 2013)

PPD muncul dari lokasi timbulnya luka (Saravanan et.al, 2015). Luka diartikan dalam arti luas sebagai keadaan ketika umbi telah dipisahkan dari akar di dalam tanah dan dari batang. Umbi ubi kayu merupakan organ penyimpanan untuk fotosintesis bukan untuk propagulasi dengan fungsi reproduksi sehingga tidak ada kemampuan untuk memperbaiki luka ketika umbi sudah dilepaskan dari akarnya. Secara visual, terdapat tiga bagian pada penampang melintang umbi yaitu; peel, central pith dan vascular bundle (Gambar 2) (FAO, 1999). Kerusakan fisiologis mulai muncul pada hari ke-7 penyimpanan. Baik varietas $R$ maupun U yang disimpan dengan kontrol, cenderung menunjukkan warna biru kehitaman dan sedikit 


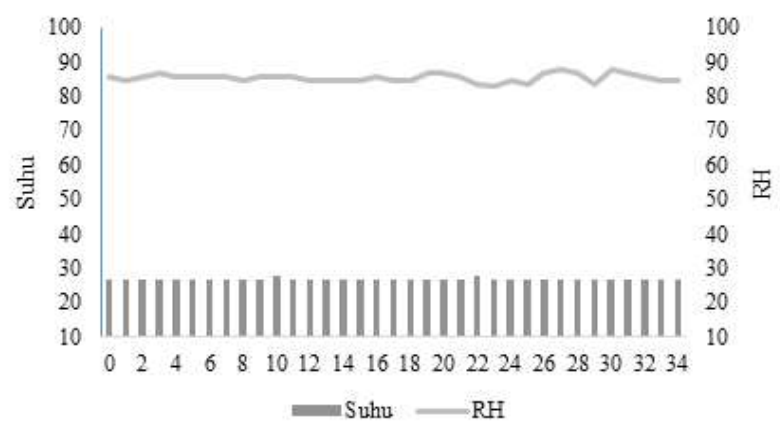

Gambar 1. Suhu dan RH di dalam kotak kayu selama penyimpanan

pen--coklatan pada bagian central pith. Kerusakan ini terjadi sejak hari ke-7 (Gambar 3) hingga hari ke35 penyimpanan (Gambar 5). Sementara itu pada varietas $\mathrm{R}$ dan $\mathrm{U}$ yang disimpan di dalam kotak kayu berlapis serbuk kayu, tidak terjadi kerusakan fisiologis sejak hari ke-7 (Gambar 4) hingga hari ke-28 penyimpanan (Gambar 6).

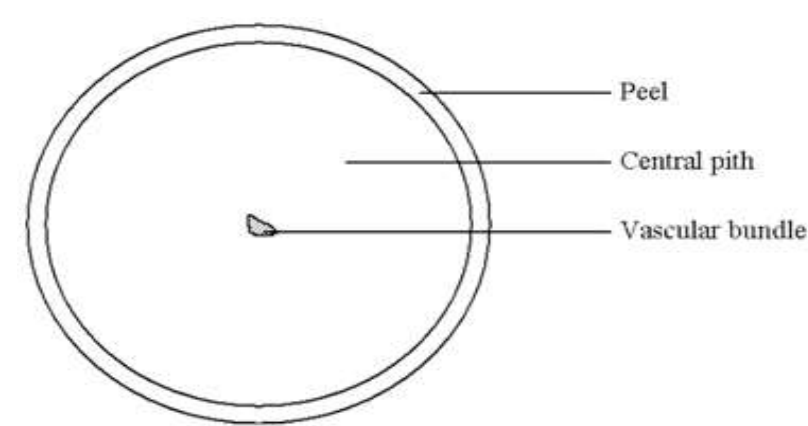

Gambar 2. Tiga bagian pada penampang melintang umbi

Tahap pertama dalam proses PPD adalah terbentuknya spesies reaktif oksigen (ROS) seperti superoksidasi radikal $\left(\mathrm{O}_{2}-\right)$, hidroksil radikal $(\mathrm{OH})$ dan hidrogen peroksida $\left(\mathrm{H}_{2} \mathrm{O}_{2}\right)$ yang mengubah ekspresi gen dan akumulasi metabolit sekunder (Zidenga et.al, 2012). Tumbuhan dan organisme hidup lainnya dalam lingkungan yang teroksidasi selalu menghasilkan ROS

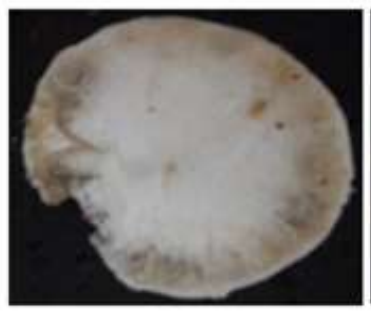

$\mathrm{R}$

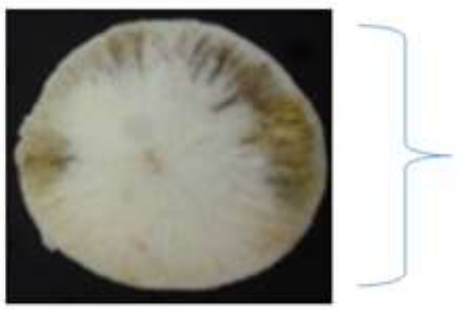

$\mathrm{U}$

\section{Central pith}

Gambar 3. Kerusakan Fisiologis pada varietas $\mathrm{R}$ dan U dengan kontrol pada hari ke 7

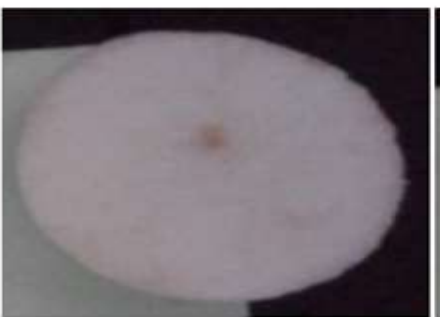

$\mathrm{R}$

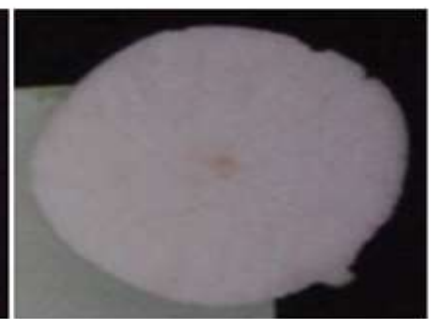

$\mathrm{U}$

Gambar 4. Varietas $\mathrm{R}$ dan $\mathrm{U}$ dengan penyimpanan dalam kotak kayu pada hari ke 7 penyimpanan 


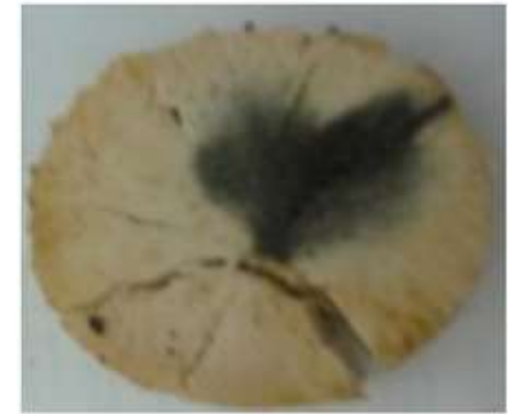

$\mathrm{R}$

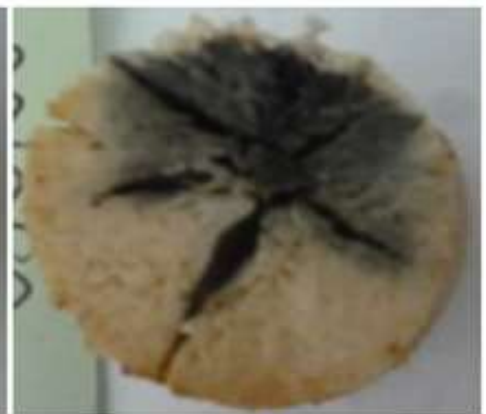

$\mathrm{U}$

Gambar 5. Kerusakan Fisiologis pada varietas R dan U dengan kontrol pada hari ke 35 penyimpanan

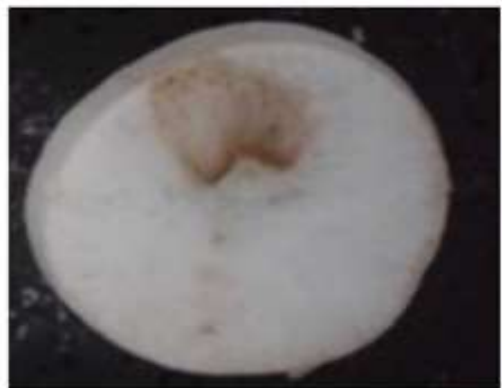

$\mathrm{R}$

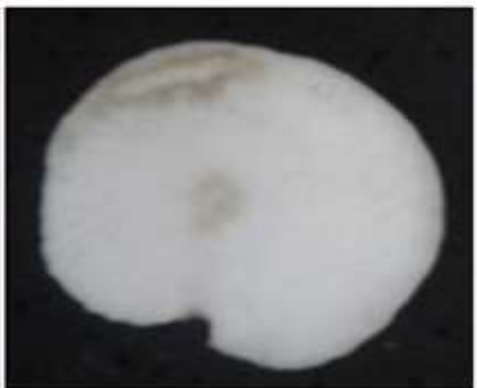

$\mathrm{U}$

Gambar 6. Kerusakan Fisiologis pada varietas R dan U dengan kotak kayu dan serbuk gergaji pada hari ke 28 penyimpanan

dari kloroplas, mitokondria, peroksisom dan organela subseluler lainnya karena proses metabolisme seperti fotosintesis dan respirasi. Kelebihan produksi ROS dipicu oleh serangan patogen atau stress yang disebabkan oleh kondisi lingkungan dapat menyebabkan kerusakan sel (Djabou et.al, 2017).

Spesies reaktif oksigen merupakan senyawa pengoksidasi turunan oksigen yang bersifat sangat reaktif yang terdiri atas kelompok radikal bebas dan kelompok non radikal. Oksigen menjadi reaktif ketika struktur elektronnya dikonversi ke spesies reaktif oksigen seperti singlet oxygen $\left(\mathrm{O}_{2}\right)$, superoxide radical $\left(\mathrm{O}_{2}\right)$, hydrogen peroxide $\left(\mathrm{H}_{2} \mathrm{O}_{2}\right)$, dan hydroxyl radical $\left(\mathrm{OH}^{-}\right)$. Formasi ROS telah ditunjukkan terjadi dengan cepat pada ubi kayu yang telah dipanen: $\mathrm{O}_{2}{ }^{-}$dalam 15 menit, $\mathrm{O}_{2}$ dalam 3 atau 4 jam, $\mathrm{H}_{2} \mathrm{O}_{2}$ dalam 3-24 jam dan $\mathrm{OH}^{-}$dalam 36 jam (Getzin dan Fellman, 2011). Radikal bebas adalah suatu molekul yang pada lapisan elektron terluarnya tidak mempunyai elektron berpasangan. Akibatnya radikal bebas akan selalu berusaha mengambil elektron dari molekul atau senyawa lain di sekitarnya. Apabila radikal bebas mengambil elektron dari protein, lemak, asam nukleat dari suatu sel maka komponen protein, lemak dan asam nukleat dari sel tersebut akan berubah dan fungsi sel tersebut akan terganggu (Reilly et.al, 2004).

Selain ROS, metabolit sekunder seperti senyawa polifenol juga berperan dalam proses PPD pada ubi kayu. Telah dibuktikan bahwa polifenol 
meningkat selama proses PPD pada ubi kayu. Senyawa fenolik yang terkait dengan perkembangan penurunan fisiologis telah diidentifikasi dan termasuk scopoletin, scopolin, esculin, proanthocyani proanthocyanidins, catechin, dan gallocatechin. Produksi scopoletin dan beberapa senyawa yang berhubungan dengan skopolin tampaknya berkontribusi pada peningkatan fluoresensi perubahan warna selama proses PPD pada ubi kayu. Oksigen diperlukan untuk memulai proses PPD (Huang et.al, 2001). Scopoletin berperan dalam pengembangan PPD pada ubi kayu. Ketika diterapkan pada umbi yang baru dipotong, scopoletin mampu menghasilkan perubahan warna yang intens dan cepat di dalam jaringan. Diantara berbagai senyawa fenolik yang diterapkan pada jaringan yang dipanen, hanya scopoletin yang menyebabkan perubahan warna yang signifikan (Mattinson et al, 2010). Scopoletin dapat dideteksi oleh fluoresensi dalam sinar UV karena itu membentuk kompleks biru ketika dioksidasi oleh ROS dan enzim peroksidase yang berkontribusi terhadap perubahan warna biru-hitam pada ubi kayu selama penyimpanan (Zainuddin et.al, 2017).

Terdapat hubungan yang sangat kuat antara peristiwa hidrolisis HCN melalui sianogenesis dengan munculnya ROS pada tahap awal kerusakan fisiologis. gangguan jaringan akibat luka saat panen menginisiasi sianogenesis melalui kontak antara linamarin dengan enzim linamarase. Sianida atau HCN menghambat rantai transport elektron dalam mitokondria di kompleks IV. Akibatnya, kompleks IV menghasilkan ROS yang dimunculkan melalui kompleks 1 dan III dalam rantai transport elektron. ROS inilah yang kemudian menyebabkan terjadinya persitiwa kerusakan fisiologis pada umbi (Zidenga et.al, 2012 dan Reilly et.al, 2004).

Seperti yang terlihat pada Tabel 2, perlakuan RP2 dan UP2 cenderung mengalami kenaikan persentase kerusakan fisiologis hingga akhir penyimpanan. Berbeda dengan RP1 dan UP1 yang tidak mengalami kerusakan fisiologis selama 28 hari penyimpanan. Kerusakan fisiologis terjadi pada hari ke-35 penyimpanan dengan persentase kurang dari $25 \%$.

\section{Kerusakan Mikrobiologis}

Kerusakan mikrobiologis terjadi ketika umbi sudah menjadi tidak layak lagi akibat kerusakan fisiologis (Uarrota et.al, 2015). Kerusakan ini tampak sebagai bentuk kebusukan umbi. Kerusakan ini

Tabel 2. Tingkat kerusakan fisiologis ubi kayu selama penyimpanan

\begin{tabular}{ccccccc}
\hline \multirow{2}{*}{ Perlakuan } & \multicolumn{7}{c}{ *Tingkat kerusakan vaskular (\%) pada hari ke- } \\
\cline { 2 - 6 } & 0 & 7 & 14 & 21 & 28 & 35 \\
\hline RP2 & 0 & 25 & $26-50$ & 50 & $76-100$ & $76-100$ \\
RP1 & 0 & 0 & 0 & 0 & 0 & $<25$ \\
UP2 & 0 & 25 & $26-50$ & 50 & $76-100$ & $76-100$ \\
UP1 & 0 & 0 & 0 & 0 & 0 & $<25$ \\
\hline
\end{tabular}

*Nilai rata-rata ulangan 
Tabel 3. Tingkat kerusakan mikrobiologis pada ubi kayu selama penyimpanan

\begin{tabular}{ccccccc}
\hline \multirow{2}{*}{ Perlakuan } & \multicolumn{6}{c}{ *Tingkat kerusakan mikrobiologis (\%) pada hari ke } \\
\cline { 2 - 7 } & 0 & 7 & 14 & 21 & 28 & 35 \\
\hline RP2 & 0 & 0 & 0 & $21-40$ & $41-60$ & $81-100$ \\
RP1 & 0 & 0 & 0 & 0 & 0 & 0 \\
UP2 & 0 & 0 & 0 & $21-40$ & $41-60$ & $81-100$ \\
UP1 & 0 & 0 & 0 & 0 & 0 & 0 \\
\hline
\end{tabular}

*Nilai rata-rata ulangan

ditandai oleh perubahan warna umbi menjadi kekuningan dan diikuti oleh pelunakan. Aroma umbi juga mengalami perubahan menjadi aroma sedikit asam dan cenderung sedikit busuk.

Berdasarkan Tabel 3, persentase kerusakan mikrobiologis pada RP2 dan UP2 mengalami peningkatan sejak hari ke-21 hingga akhir penyimpanan. Sementara itu perlakuan RP1 dan UP1 tidak mengalami kerusakan mikrobiologis selama penyimpanan. Kerusakan mikrobiologi tampak seperti pada Gambar 6.

\section{KESIMPULAN}

Kerusakan fisiologi terjadi pada ubi kayu yang disimpan dengan kondisi kontrol yaitu pada perlakuan RP2 dan UP2. Kerusakan ini terjadi pada hari ke-7 penyimpanan dengan tingkat kerusakan yang cenderung meningkat hingga akhir penyimpanan. Sementara itu kerusakan mikrobiologis mulai terjadi pada hari ke-14 dengan persentase yang juga terus mengalami peningkatan. Berbeda halnya dengan ubi kayu yang disimpan dengan kotak kayu dan serbuk kayu yaitu pada perlakuan RP1 dan UP1. Kerusakan fisiologis mulai terjadi pada hari ke-28 penyimpanan dan tidak mengalami kerusakan mikrobiologis. Penyimpanan ubi kayu di dalam kotak kayu yang diselimuti serbuk kayu lembab memberikan hasil yang cenderung lebih baik dibandingkan kontrol. Penggunaan serbuk kayu lembab mampu menciptakan kondisi lingkungan yang optimum untuk penyimpanan ubi kayu.

\section{DAFTAR PUSTAKA}

Khumaida N, Ardie S, Dianasari M, Syukur M. 2015. Cassava (Manihot esculenta Crantz.) improvement through gamma irradiation. Procedia Food Science. (3) 27-34

Yani RH, Khumaida N, Ardie SW, Syukur M. 2018. Analysis of Variance, Heritability, Correlation and Selection Character of M1V3 Generation Cassava (Manihot esculenta Crantz) $\mathrm{Mu}-$ tants. AGRIVITA Journal of Agriculture Sciences. 40(1), 74-79.

Ginting E. 2002. Teknologi penanganan pascapanen dan pengolahan ubi kayu menjadi produkantara untuk mendukung agroindustri. Bul. Palawija. (4): 67-83.

Haloho JH. 2014. Pengolahan Ubi kayu Dalam Upaya Percepatan Diversifikasi Pangan Di Kalimantan 
Barat. Prosiding Seminar Hasil Penelitian Tanaman Aneka Kacang dan Umbi 2014.

Noerliyanti I. 2017. Analisis karakteristik dan umur simpan beberapa genotip ubi kayu (Manihot esculenta Crantz.) hasil pemuliaan [skripsi]. Bogor (ID): Institut Pertanian Bogor

Osunde ZD, Fadeyibi A. 2011. Storage methods and some uses of cassava in Nigeria. Continental J. Agricultural Science. Vol 5(2): 12-18.

Quevedo MA, Arsenio DR, Ness Mlsta.iglesia. 2014. Evaluation of appropriate storage technologies for shelf-life improvement of cassava (Manihot esculenta Crantz) roots for marginal upland farmers. Annuals of tropical research. (36): 139153.

Babarinsa OA, Oluwalana IB. 2018. Effect of storage of fresh cassava in sawdust on gari processing. Journal of Postharvest Technology. Vol 6(1): 57-62.

Maharani R, Tamai Y, Takashi Y. 2010. Scrutiny On Physical Properties Of Sawdust From Tropical Commercial Wood Species: Effects Of Different Mills And Sawdust's Particle SizeAnd Terazawa Minoru. Journal of Forestry Research Vol. 7(1).

Saravanan R, Patel J, Chakrabarti SK. 2015. Evaluation of postharvest physiological deterioration in storage roots of cassava (Manihot esculenta Crantz) genotypes. Indian Journal of Agricultural Sciences. Vol 85 (10): 1279 84.

Sa'nchez T, Dufour D, Moreno JL, Pizarro M, Arago'n IJ, Domý'nguez M, Ceballos. 2013. Changes in extended shelf life of cassava roots during storage in ambient conditions. Postharvest Biol Technol. 86:520-528.

[FAO] Food and Agriculture Organization. 1999. CASSAVA: Post-harvest Operations.

Zidenga T, Leyva-guerrero E, Moon H, Siritunga D, Sayre R. 2012. Extending cassava root via reduction of reactive oxygen species production. Plant physiol. 159 (4), 1396-1407.

Djabou ASM, Carvalho, LJCB, Li QX, Niemenak N, Chen S. 2017. Cassava post harvest physiological deterioration: a complex phenomenon involving calcium signaling, reactive oxygen species and programmed cell death. Acta physiol. Plant. Vol 39 (4): 91.

Getzin EM, Fellman JK. 2011. Confocal imaging studies of postharvest physiological deterioration in cassava (Manihot esculenta Crantz) root tissue. Toivonen (Ed.), Proc. 4th International Conference Postharvest Unlimited 2011. Acta Hort Vol 945: 113-118.

Reilly K, Gómez-vásquez R, Buschmann H, Tohme J, Beeching JR. 2004. Oxidative stress responses during cassava post-harvest physiological deterioration. Plant mol. Biol. Vol 56 (4): 625641.

Huang J, Bachem C, Jacobsen E, Visser RG. 2001. Molecular analysis of differentially expressed genes during postharvest deterioration in cassava (Manihot esculenta Crantz) tuberous roots. Euphytica. Vol 120: 85-93.

Mattinson IS, Fellman JK. 2010. Study of the early events leading to cassava root postharvest deterioration. Trop. Plant Biol. 3 (3), 151-165. 
Zainuddin IM, Fathoni A, Sudarmonowati E, Beeching JR, Gruissem W, Vanderschuren H. 2017. Cassava post-harvest physiological deterioration: From triggers to symptoms. Postharvest Biology and Technology
Uarrota VG, Nunes de Corta, Peruch M. 2015. Toward better understanding of postharvest deterioration: biochemical changes in stored cassava (Manihot esculenta Crantz) roots. Food Science \& Nutrition. Vol 4(3): 409422. 